\title{
Germination Responses of Eysenhardtia texana and Leucaena retusa
}

\author{
S.G. WHISENANT AND D.N. UECKERT
}

\section{Abstract}

Germination and radicle growth of kidneywood and little-leaf leadtree were greatest at $30^{\circ} \mathrm{C}$ but occurred under a wide range of temperatures. Germination and radicle growth of kidneywood seed did not differ over the pH range of 5 to 9 . Germination of little-leaf leadtree was lower at pH 5 and 6 than at pH 7 to 9. Decreased water availability reduced germination and radicle length of both species; however, kidneywood seed germination was more tolerant of moisture stress than little-leaf leadtree. Seeds of both species maintained high viability for at least $\mathbf{4 2}$ months after collection. An impervious seedcoat prevents germination of littleleaf leadtree seeds until it is scarified. Results from these experiments indicated no significant germination problems will be encountered in attempts to establish these plants under field conditions.

Production of livestock and wildlife in much of the arid and semiarid areas of the world is limited because range forages are deficient in protein. Leguminous forage shrubs can potentially increase the quantity and quality of feed available in arid and semiarid areas. Woody legumes are less susceptible to seasonal droughts than are herbaceous species and can supplement animal diets during dry periods. The use of woody legumes to increase soil nitrogen and to provide high-protein feed well into the dry season has dramatically increased animal production in both humid and arid areas of the tropics (Jones 1979). This study was undertaken to evaluate the germination characteristics of two leguminous shrubs, Eysenhardtia texana Scheele (kidneywood) and Leucaena retusa Gray (little-leaf leadtree), native to arid and semiarid regions of Texas and Mexico, which are believed to have great potential as forage shrubs. This information on germination responses to simulated environmental parameters should identify any significant germination barriers to field establishment of kidneywood and little-leaf leadtree.

Kidneywood is a shrub which grows from 1 to $4 \mathrm{~m}$ tall on calcareous soils of South, Central, and West Texas and south into Mexico (Correll and Johnston 1970). In the drier a reas of West Texas kidneywood is mainly found along dry arroyos (Warnock 1970). Kidneywood is considered an excellent browse plant for livestock and wildlife. Krausemann (1978) listed kidneywood as a foud of desert mule deer(Odocoileus hemionus crooki) in Big Bend National Park in Texas. Anthony and Smith (1977) reported that desert southwest rangeland dominated by kidneywood ( $E$. polystachya) was heavily utilized by deer during the hot, dry season, which is the most critical period of the year for desert southwest deer herds.

Little-leaf leadtree is a shrub or small tree which may grow to $5 \mathrm{~m}$ tall. It occurs principally on dry, well-drained, rocky soils in Central and West Texas and in Coahuila Mexico (Correll and Johnston 1970, Vines 1960). Little-leaf leadtree is readily browsed by wildlife and livestock (Lamb 1975, Vines 1960; Warnock 1977) and has been recommended as an ornamental (Vines 1960, Warnock

Authors are research associate and professor, Texas Agricultural Experiment Station at San Angelo. Whisenant's present address is Dept. of Botany and Range Science, Brigham Young University, 401 WIDB, Provo, Utah 84602.

This report is approved by the Director, Texas Agricultural Experiment Station as TA-16365.

Manuscript received September 24, 1980.
1977) because of its brilliant golden globose flowers. The Texas Organization for Endangered Species included little-leaf leadtree in a list of rare and endangered plants (Rowell 1975) of Central and West Texas. Little-leaf leadtree has many characteristics similar to the closely related but more tropical $L$. leucocephala (koa haole) which is widely used throughout the tropics for forage. It is one of the highest yielding, high-quality legumes of the tropics (Brewbaker et al. 1972, Jones 1979, Oakes 1968, Takahashi and Ripperton 1949). Sheep may shed their wool 1 to 2 weeks after beginning a steady diet of koa haole and continued feeding may result in death
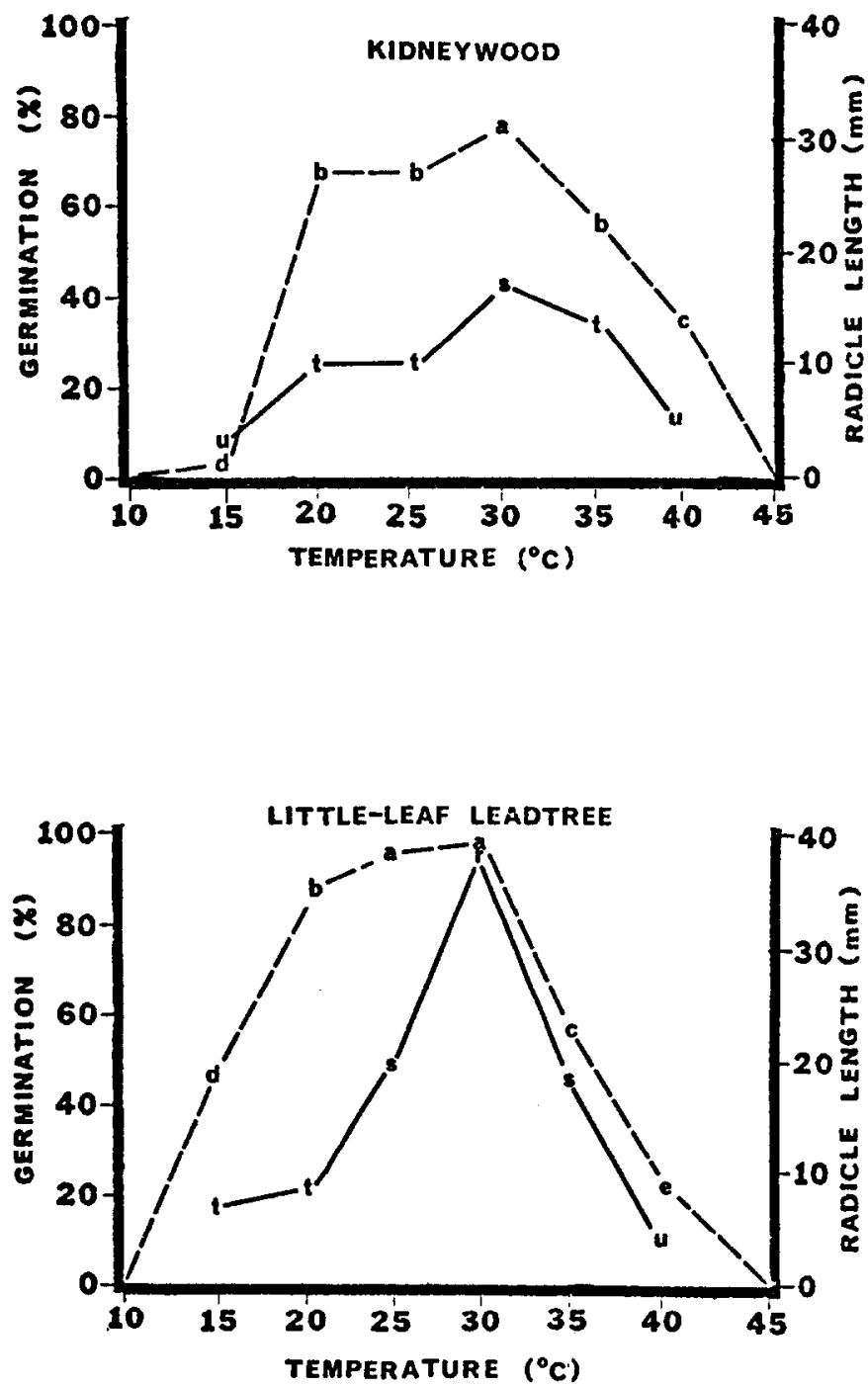

Fig. 1. Germination and radicle elongation of kidneywood seed (top) and little-leaf leadtree seed (bottom) after 10 days at various constant temperatures. Germination response is indicated by a dashed line and radicle elongation by a solid line. Means with similar lower case letters are not significantly different at $\mathrm{P}<0.05$. 
due to a toxic amino acid (mimosine) found in all parts of the plant. However, this toxicity has not been observed under natural field conditions (Jones 1979).

\section{Materials and Methods}

Kidneywood and little-leaf leadtree seeds used in this study were collected during 1976 and 1978, from plants growing at the Soil Conservation Service Plant Materials Center at Knox City, Texas. Kidneywood plants at Knox City were grown from seeds collected near Uvalde, Texas, and little-leaf leadtrees were grown from seeds collected near Junction, Texas. Seeds harvested in 1976 were used to determine the length of viability and the 1978 accession was used for all other experiments. Seeds were stored at room temperature $\left(24^{\circ} \mathrm{C} \pm 3^{\circ} \mathrm{C}\right)$ until used in experiments. Seeds were tested for seed coat dormancy by comparing germination of unt reated seeds with that of seeds which had the testa perforated with a scapel. Germination studies were conducted using 6 replications of 40 fully developed and undamaged seeds in $10-\mathrm{cm}$ diameter petri dishes. Two Whatman No. 3 filter papers saturated with $7 \mathrm{ml}$ (kidneywood) or $8 \mathrm{ml}$ (little-leaf leadtree) of distilled water or various test solutions were used as the germination substrate. The petri dishes were randomly arranged on moist paper toweling in a sealed box inside an environmental chamber. Germination percentage and radicle length were recorded at the end of 10-day trial. Seeds were considered to have germinated when the radicle was at least $1 \mathrm{~mm}$ (kidneywood) or $3 \mathrm{~mm}$ (little-leaf leadtree) long. Each experiment was repeated 2 to 5 times and the data pooled for presentation.

The effect of constant temperature on germination and radicle elongation was evaluated at $5^{\circ} \pm 1^{\circ} \mathrm{C}$ increments between $10^{\circ}$ and $45^{\circ} \mathrm{C}$. All other experiments were conducted at $30^{\circ} \mathrm{C}$. Light requirements were investigated by comparing germination of seeds in petri dishes covered with aluminum foil with that of seeds in transparent dishes. All other experiments were conducted under constant lighting from fluorescent and incandescent sources.

The effects of moisture stress on germination and radicle elongation were studied at $30^{\circ} \mathrm{C}$ using aqueous solutions of polyethylene glycol (PEG) 6000 . The solutions were mixed by the method described by Michel and Kaufmann (1973) to exert osmotic potentials of $-2,-4,-8$ and -12 bars. Distilled water was used for the 0 bars treatment. The pH of these PEG solutions was 7.2

The effect of $\mathrm{pH}$ on germination and radicle elongation was investigated at $30^{\circ} \mathrm{C}$ by adjusting the hydrogen ion concentration of distilled water with $\mathrm{HCL}$ and $\mathrm{KOH}$. This approach avoided the potential osmotic effects cxerted by buffered solutions (Scifres and McCarty 1969). The change in $\mathrm{pH}$ of these unbuffered solutions was minimal (from 0.1 to 0.2 unit change). A range of $\mathrm{pH}$ values from 5 to 9 in whole unit increments was used.

The effects of age on seed viability was evaluated by germinating seeds at 3-month intervals from date of collection in 1976 to 42 months after seed collection.

Germination data were subjected to $\arcsin \sqrt{\mathbf{P}} \quad(\mathbf{P}=$ proportion germinated) transformation prior to conducting analyses of variance. No transformation was applied to radicle lengths. Differences among treatment means within an attribute were determined with Duncan's multiple range tests where appropriate.

\section{Results and Discussion}

One of the most important of the specific conditions that must be met during seed germination is temperature (Toole et al. 1956). The minimum temperaturc for germination of both species was $15^{\circ} \mathrm{C}$ with $2 \%$ and $44 \%$ germination of kidneywood and little-leaf leadtree, respectively (Fig. 1). The maximum temperature for germination of both species was $40^{\circ} \mathrm{C}$ with $35 \%$ and $9 \%$ germination of kidneywood and little-leaf leadtree, respectively. The optimum constant temperature for germination and radicle elongation of both species was $30^{\circ} \mathrm{C}$. At $30^{\circ} \mathrm{C}, 75 \%$ of the kidneywood seeds and $99 \%$ of the little-leaf leadtree seeds germinated.

Germination response of kidneywood seed to moisture stress demonstrated an ability to withstand some stress without a signifi-
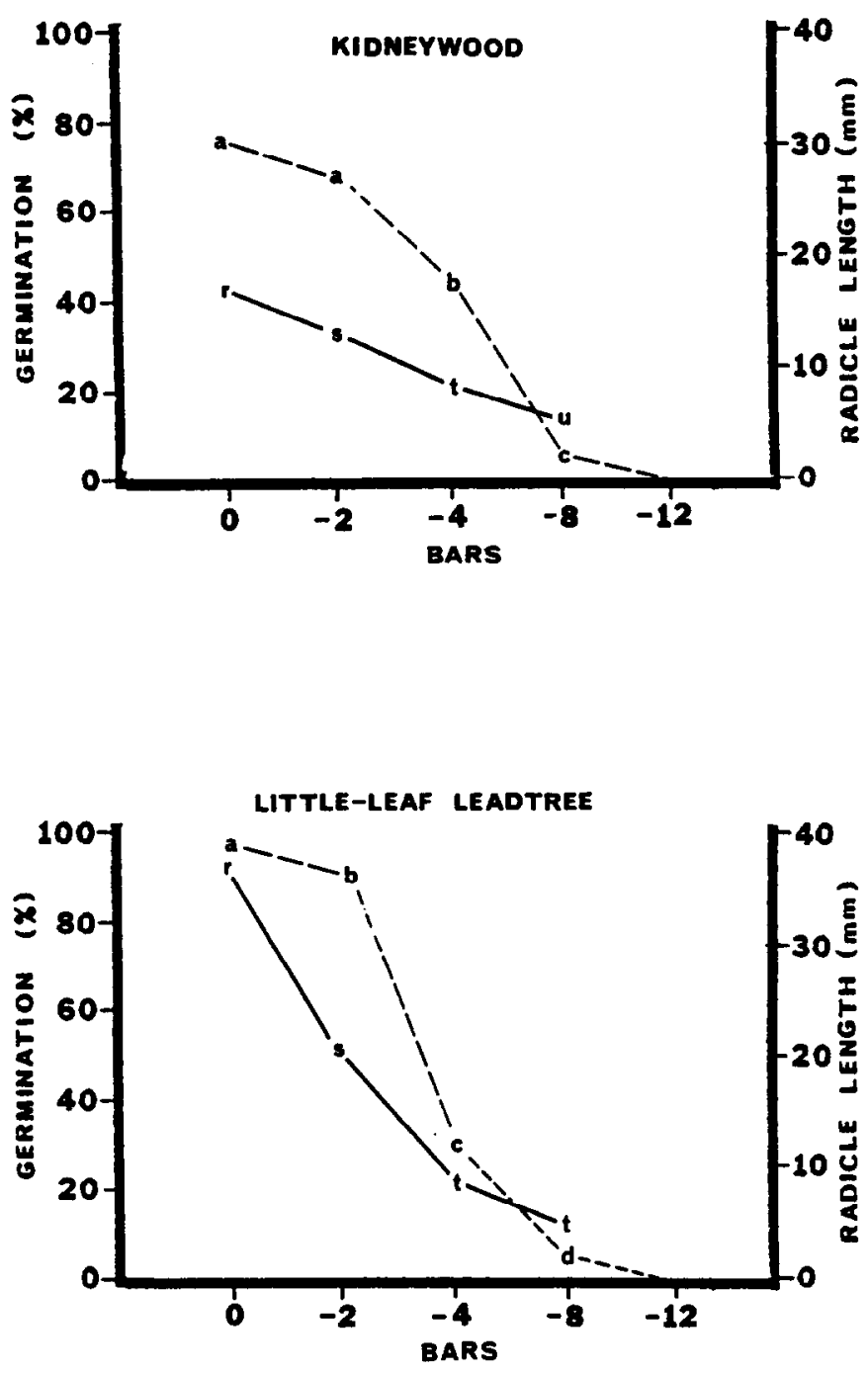

Fig. 2. Germination and radicle elongation of kidneywood seed (top) and little-leaf leadtree seed (bottom) after 10 days at various moisture tensions at $30^{\circ} \mathrm{C}$. Germination response is indicated by a dashed line and radicle elongation by a solid line. Means with similar lower case letters are not significantly different at $\mathrm{P}<0.05$.

cant decrease in germination. However, increasing moisture stress significantly $(P<0.05)$ decreased radicle elongation of kidneywood seedlings (Fig. 2). Seed germination and radicle length of little-leaf leadtree seedlings were progressively reduced by increasing osmotic potential (Fig. 2). It is possible that the osmotic potentials of these solutions may have changed during the 10-day germination experiments because of evaporation from the petri dishes. However, placing the dishes on the moist towels in the sealed glass box should have minimized this possibility.

There were no significant $(P<0.05)$ differences in seed germination or radicle elongation of kidneywood seedlings at media $\mathrm{pH}$ values of 5 to 9 (data not shown). Little-leaf leadtree seed germination was favored by an alkaline medium and germination decreased with increasing acidity. Germination of little-leaf leadtree seed was higher at $\mathrm{pH}$ media values of 7 to 9 compared to $\mathrm{pH}$ values of 5 and 6 . However, little-leaf leadtree radicle growth was not significantly different $(P<0.05)$ among the $\mathrm{pH}$ treatments imposed (data not shown).

The ability of seeds to retain viability for prolonged periods without germination is one of the most important adaptive and survival properties of plants, allowing survival during adverse seasonal conditions and providing for the storage of seeds in the 
soil (Nikolaeva 1977). In the case of leguminous plants, the failure to germinate rapidly is often attributed to the impermeability of the seed coat to water. This impermeability is caused by the cuticle and an extensively developed layer of palisade cells (Nikolaeva 1977). Under natural conditions, alternating extremes of temperatures, microbial action and abrasion against soil particles erode the coat and increase permeability, thus permitting imbibition (McDonough 1977). Kidneywood seed germination was unaffected by nicking the testa with a scapel. However, this treatment increased germination of little-leaf leadtree seeds from $4 \%$ to $98 \%$.

Neither kidneywood or little-leaf leadtree seeds required light for germination at $30^{\circ} \mathrm{C}$ (data not shown). Germination of kidneywood or little-leaf leadtree seeds did not decrease significantly from collection to 42 months post-collection (data not shown).

\section{Conclusions}

Kidneywood and little-leaf leadtree are leguminous shrubs with potential for increasing forage quality for livestock and wildlife during the hot, dry months in the arid and semiarid regions of the world. No significant germination problems were observed which would prevent successful establishment of either species in most field situations. With respect to germination and radicle growth, both species are tolerant of a wide range of temperature and $\mathbf{p H}$. Optimum temperature for germination and radicle elongation of both species was $30^{\circ} \mathrm{C}$; no germination occurred below $15^{\circ} \mathrm{C}$ or above $40^{\circ} \mathrm{C}$. Germination and radicle elongation of both species decreased with increasing moisture tension but effects of $\mathrm{pH}$ were minimal within the range $\mathrm{pH} 5$ to 9 . Mechanical scarification increased germination of little-leaf leadtree seeds but not those of kidneywood. Neither species required light for germination and seeds of both species germinated as well at 42 months after collection as at $\mathbf{3}$ months after collection. The little-leaf leadtree produced stronger and more vigorous radicles than kidneywood under the conditions of this experiment. This more aggressive radical growth suggests that little-leaf leadtree may be more successful in seedling establishment than kidneywood. Monsen and Christensen (1975) indicated that slow developing shrubs are likely to succumb if weeds are not eliminated prior to seeding, and that shrubs with aggressive seedlings are especially desirable for rehabilitating rangelands.

\section{Literature Cited}

Anthony, R.G. and N.S. Smith. 1977. Ecological relationships between mule deer and white-tailed deer in southeastern Arizona. Ecol. Monogr. 47:255-277.

Brewbaker, J.L., D.L. Plucknett and V. Gonzalez. 1972. Varietal variations and yield trials of Leucaena leucocephala (Koa Haole) in Hawaii. Hawaii Agric. Exp. Sta. Res. Bull. 166. 29 p.

Correll, D.S. and M.C. Johnston. 1970. Manual of the vascular plants of Texas. Tex. Res. Found. Renner, Texas 1881 p.

Jones, R.J. 1979. The value of Leucaena leucocephala as a feed for ruminants in the tropics. World Animal Rev. 31:13-23.

Krausemann, P.R. 1978. Forage relationships between two deer species in Big Bend National Park, Texas. J. Wildl. Manage. 42:101-107.

Lamb, S.H. 1975. Woody plants of the southwest. Sunstone Press. Santa Fe, New Mexico. 177 p.

McDonough, W.T. 1977. Seed physiology, p. 155-184. In: Range Plant Physiology (R.E. Sosebee, ed.) Range Sci. Ser. No. 4. Soc. Range Manage. Denver, Colo.

Michel, B.E. and M.R. Kaufmann. 1973. The osmotic potential of polyethelene glycol 6000. Plant Physiol. 51:914-916.

Monsen, S.B. and D.R. Christensen. 1975. Woody plants for rehabilitating rangelands in the Intermountain Region, p. 72-119. In: "Wildland Shrubs" Symposium and Workshop Proceedings. Provo, Utah. November 1975.

Nikolaeva, M.G. 1977. Factors controlling the seed dormancy pattern, in the physiology and biochemicstry of seed dormancy and germination. Elsevier/North-Holland Biomedical Press. 220 p.

Oakes, A.J. 1968. Leucaena leucocephala: description-culture-utilization. Adv. Front. Plant Sci. Vol. 20. 113 p.

Rowell, C.M. 1975. Selected rare and endangered plants of Texas. Texas Organization for Endangered Species. San Angelo, Texas. (mimeo) $50 \mathrm{p}$.

Scifres, C.J., and M.K. McCarty. 1969. Some factors affecting germination and seedling growth of scotch thistle. Nebraska Agr. Exp. Sta. Bull. 228. $28 \mathrm{p}$.

Takahashi, M., and J.C. Ripperton. 1949. Koa haole (Leucaena glauca). Its establishment, culture and utilization as a forage crop. Hawaii Agr. Exp. Sta. Bull. $100.56 \mathrm{p}$.

Toole, E.H., S.B. Hendricks, H.A. Borthwick, and W.K. Toole. 1956. Physiology of seed germination. Ann. Rev. Plant Physiol. 7:229-324.

Vines, R.A. 1960. Trees, shrubs and woody vines of the southwest. Univ. Texas Press, Austin . 1104 p.

Wamock, B.H. 1970. Wildflowers of the Big Bend Country, Texas. Sul Ross State Univ. Alpine, Texas. $157 \mathrm{p}$

Wamock, B.H. 1977. Wildflowers of the Davis Mountains and Marathon Basin Texas. Sul Ross State Univ. Alpine, Texas. 274 p. 